JUURNAL

of Health Inequalities

\title{
Nutritional habits and lifestyle of patients qualified for Roux-en-Y gastric bypass and sleeve gastrectomy bariatric surgery
}

\author{
Natalia Komorniak', Monika Hoffmann', Bartosz Kowalewski², Krzysztof Kaseja ${ }^{3}$, Małgorzata Szczuko $^{1}$ \\ 'Department of Human Nutrition and Metabolomics, Pomeranian Medical University in Szczecin, Poland \\ ${ }^{2}$ Independent Provincial Public Hospital Complex in Szczecin-Zdunowo, Poland \\ IIndependent Public Clinical Hospital No. 2 Pomeranian Medical University in Szczecin, Poland
}

\begin{abstract}
Introduction: Obesity is a disease affecting an increasing number of people around the world. Studies show that the diet of obese patients is qualitatively poor, which is linked to many vitamin and mineral deficiencies in this group of patients.

Aim of the study: To determine whether selected elements of patients' lifestyle contributed to the occurrence of extreme obesity among them.

Material and methods: The study involved 60 patients qualified for surgical treatment. A survey related to dietary habits was conducted and anthropometric measurements were taken. For the survey used in this study the questionnaire contained questions on: socio-economic situation, health condition, presence of diseases accompanying obesity, dietary habits and physical activity. All the results were statistically analysed using the STATISTICA 12 software.

Results: As many as $75 \%$ of women and $80.5 \%$ of men qualified for the two types of surgeries led a sedentary lifestyle and did not engage in any physical activity. Majority of patients ate only 2-3 meals a day at irregular intervals and snacked between meals. Approximately $1 / 3$ of patients did not eat breakfasts and $1 / 5$ ate meals during the night. Women most often snacked under stress and men snacked as a habit in front of the TV/computer.

Conclusions: Dietary habits and a sedentary lifestyle were the main contributors to the development of obesity, along with eating to reduce stress. A consultation with a psychologist would help patients to reduce excessive body weight.
\end{abstract}

KEY WORDS: bariatric surgery, obesity, feeding behaviour, sedentary lifestyle, eating disorders.

ADDRESS FOR CORRESPONDENCE: Małgorzata Szczuko, Department of Human Nutrition and Metabolomics, Pomeranian Medical University in Szczecin, 24 Broniewskiego St., 71-460 Szczecin, Poland, e-mail: malgorzata.szczuko@pum.edu.pl

\section{INTRODUCTION}

Throughout the last decades, obesity has gained a prominent place among other non-infectious chronic diseases as a serious health problem in many countries [1]. According to data from World Health Organization (WHO), in 2014 there were more than 1.9 billion overweight adults globally, including more than 600 million obese people. A study published in 2015 [2] showed that almost half of adult Europeans (47.6\%) is overweight (54.5\% of men and $40.8 \%$ of women), and $12.8 \%$
( $14 \%$ of men and $11.5 \%$ of women) is obese. Paradoxically, despite the fact that obesity is a preventable disease, most people live in countries where excessive weight and obesity kill more people than malnutrition - it is the fifth cause of deaths in the world. Obesity is the most common pathological state leading to significant deterioration in the health of all social groups in developed countries [3].

Obesity is characterized by increased amount of fatty tissue due to hypertrophy and/or hyperplasia of adipocytes. In people with excessive body mass, the most 
commonly diagnosed chronic diseases are hypertension, type 2 diabetes, dyslipidaemia, sleep apnoea, coronary artery disease or some types of cancer. Obesity also increases the risk of development of non-alcoholic liver disease, cholelithiasis or gastroesophageal reflux disease $[4,5]$, as well as premature death [6].

The primal cause of obesity may be attributed to environmental factors - sedentary lifestyle and high energy diet - leading to positive energy balance $[7,8]$. The diet of obese patients is qualitatively poor. It is typically characterized by a low consumption of wholemeal products, dairy products, vegetables, fruits and fish [9]. Studies show that patients qualified for surgical treatment of obesity have deficiencies in compounds such as vitamin $\mathrm{D}_{3}$, folic acid, calcium, selenium, magnesium, iodine, iron, zinc, thiamine, pyridoxin and cobalamin [10-12], which arise due to their insufficient intake with daily diet [13]. Any actions aiming at body mass reduction in obese patients should be preceded by careful assessment of their diets, dietary habits and nutritional knowledge to find the main cause of the disease. Interdisciplinary approaches with highly qualified specialists from disciplines such as medicine, dietetics and psychology allow to obtain the best and long-lasting results in form of permanent reduction of body weight. It should be stressed that the modification of the lifestyle should last both throughout the preparation of the patient for surgery and after the procedure [14].

\section{AIM OF THE STUDY}

The aim of this study was to analyse and compare selected elements of patients' lifestyle and to determine their impact on the development of extreme obesity among patients qualified for surgical obesity treatment with two methods - restrictive and limiting the absorbance of nutrients for the rest of their life.

\section{MATERIAL AND METHODS STUDY DESIGN}

The project was approved by the Bioethical Committee of Pomeranian Medical University (resolution No KB-0012/34/04/2014). Informed consent was obtained from all individual participants included in the study. Qualification for bariatric procedure (according to National Institutes of Health criteria) [15] was performed at the Independent Public Province Complex Hospital in Szczecin-Zdunowo. The study involved 60 patients (30 women and $30 \mathrm{men}$ ), among whom 33 people (20 women and 13 men) were qualified for Roux-en-Y gastric bypass (RYGB), and 27 (10 women and 17 men) to sleeve gastrectomy (SG) procedure [16]. The most common chronic disease present among the patients was hypertension diagnosed in $40 \%$ of RYGB vs $60 \%$ of SG women and $92.31 \%$ of RYGB vs $94.12 \%$ SG men, and type 2 diabetes - in $35 \%$ of RYGB vs $20 \%$ of SG women and $46.15 \%$ of RYGB vs $47.06 \%$ of SG men. The measurements of body mass, height and waist circumference were performed with the accuracy of $0.1 \mathrm{~kg}$ or $0.5 \mathrm{~cm}$. Characterization of patients qualified for RYGB and SG procedures was shown in Tables 1 and 2.

\section{QUESTIONNAIRE}

A standardized Food Frequency Questionnaire was administered, supplemented by a proprietary survey

TABLE 1. Anthropometric data for female group

\begin{tabular}{|l|c|c|c|c|c|c|c|c|}
\hline Variable & $n$ & $\begin{array}{c}\text { Age } \\
(\text { years })\end{array}$ & $\begin{array}{c}\text { Body } \\
\text { mass }(\mathrm{kg})\end{array}$ & $\begin{array}{c}\text { Height } \\
(\mathrm{cm})\end{array}$ & $\begin{array}{c}\text { Waist } \\
\text { circumference } \\
(\mathrm{cm})\end{array}$ & $\begin{array}{c}\text { Hip } \\
\text { circumference } \\
(\mathrm{cm})\end{array}$ & $\begin{array}{c}\text { BMI } \\
\left(\mathrm{kg} / \mathrm{m}^{2}\right)\end{array}$ & WHR \\
\hline RYGB & 20 & $\begin{array}{c}44.75 \\
\pm 12.21\end{array}$ & $\begin{array}{c}132.05 \\
\pm 18.39\end{array}$ & $\begin{array}{c}168.55 \\
\pm 6.79\end{array}$ & $\begin{array}{c}137.1 \\
\pm 15.97\end{array}$ & $\begin{array}{c}142.7 \\
\pm 13.31\end{array}$ & $\begin{array}{c}46.5 \\
\pm 6.15\end{array}$ & $\begin{array}{c}0.96 \\
\pm 0.05\end{array}$ \\
\hline SG & 10 & 50.3 & 134.5 & 166.5 & 146.6 & 147.2 & 48.45 & 1.0 \\
& \pm 10.78 & \pm 20.95 & \pm 4.97 & \pm 12.31 & \pm 17.83 & \pm 6.69 & \pm 0.04 \\
\hline Statistical & NS & NS & NS & NS & NS & NS & NS \\
\hline
\end{tabular}

RYGB - Roux-en-Y gastric bypass, SG - sleeve gastrectomy, NS - statistically insignificant, BMI - body mass index, WHR - waist-to-hip ratio

TABLE 2. Anthropometric data for male group

\begin{tabular}{|c|c|c|c|c|c|c|c|c|}
\hline Variable & $n$ & $\begin{array}{c}\text { Age } \\
\text { (years) }\end{array}$ & $\begin{array}{c}\text { Body } \\
\text { mass (kg) }\end{array}$ & $\begin{array}{l}\text { Height } \\
\text { (cm) }\end{array}$ & $\begin{array}{l}\text { Waist } \\
\text { circumference } \\
(\mathrm{cm})\end{array}$ & $\begin{array}{l}\text { Hip } \\
\text { circumference } \\
\text { (cm) }\end{array}$ & $\begin{array}{c}\text { BMI } \\
\left(\mathrm{kg} / \mathrm{m}^{2}\right)\end{array}$ & WHR \\
\hline RYGB & 13 & $\begin{array}{c}47.69 \\
\pm 10.02 \\
\end{array}$ & $\begin{array}{c}140.3 \\
\pm 24.70 \\
\end{array}$ & $\begin{array}{c}180.23 \\
\pm 5.18 \\
\end{array}$ & $\begin{array}{r}141.62 \\
\pm 13.78 \\
\end{array}$ & $\begin{array}{r}130.15 \\
\pm 10.85 \\
\end{array}$ & $\begin{array}{l}43.11 \\
\pm 6.57\end{array}$ & $\begin{array}{r}1.09 \\
\pm 0.05 \\
\end{array}$ \\
\hline SG & 17 & $\begin{array}{r}47.18 \\
\pm 9.93 \\
\end{array}$ & $\begin{array}{r}149.64 \\
\pm 25.86 \\
\end{array}$ & $\begin{array}{r}179.0 \\
\pm 9.95 \\
\end{array}$ & $\begin{array}{r}144.31 \\
\pm 13.57 \\
\end{array}$ & $\begin{array}{l}133.31 \\
\pm 9.99 \\
\end{array}$ & $\begin{array}{r}46.9 \\
\pm 6.9 \\
\end{array}$ & $\begin{array}{r}1.09 \\
\pm 0.07 \\
\end{array}$ \\
\hline \multicolumn{2}{|c|}{ Statistical analysis } & NS & NS & NS & NS & NS & NS & NS \\
\hline
\end{tabular}

RYGB - Roux-en-Y gastric bypass, SG - sleeve gastrectomy, NS - statistically insignificant, BMI - body mass index, WHR - waist-to-hip ratio 
TABLE 3. Selected characteristics of patients'lifestyle

\begin{tabular}{|c|c|c|c|c|c|c|}
\hline \multirow[t]{2}{*}{ Variable } & \multicolumn{3}{|c|}{ Women } & \multicolumn{3}{|c|}{ Men } \\
\hline & RYGB (\%) & SG (\%) & $\begin{array}{c}\text { Statistical } \\
\text { analysis }\end{array}$ & RYGB (\%) & SG (\%) & $\begin{array}{c}\text { Statistical } \\
\text { analysis }\end{array}$ \\
\hline \multicolumn{7}{|l|}{ Sources of income } \\
\hline Full-time job & 50 & 70 & NS & 46.15 & 52.94 & NS \\
\hline Pension. allowance & 20 & 20 & NS & 23.08 & 29.41 & NS \\
\hline No job & 25 & 10 & NS & 15.38 & 11.76 & NS \\
\hline Other & 5 & 0 & NS & 15.38 & 5.88 & NS \\
\hline \multicolumn{7}{|l|}{ Type of work } \\
\hline Physical & 15 & 10 & NS & 15.38 & 23.53 & NS \\
\hline Intellectual & 15 & 60 & 0.001 & 30.77 & 29.41 & NS \\
\hline Mixed & 25 & 0 & NS & 15.38 & 5.88 & NS \\
\hline No job & 45 & 30 & NS & 38.46 & 41.18 & NS \\
\hline \multicolumn{7}{|l|}{ Physical activity } \\
\hline Yes & 20 & 30 & NS & 15.38 & 23.53 & NS \\
\hline No & 80 & 70 & NS & 84.62 & 76.47 & NS \\
\hline \multicolumn{7}{|l|}{ Smoking } \\
\hline Any time in life & 80 & 70 & NS & 76.92 & 82.35 & NS \\
\hline Currently & 45 & 30 & NS & 15.38 & 41.18 & NS \\
\hline
\end{tabular}

RYGB - Roux-en-Y gastric bypass, SG - sleeve gastrectomy, NS - statistically insignificant; physical activity was defined as any additional activity (e.g. walking, nordic-walking) and did not include physical work or daily duties (e.g. cleaning)

which contained the questions on selected characteristics of patients' lifestyle and dietary habits. During the study, patients were asked about their usual eating habits and not about the duration of short-term, incorrectly balanced diets (e.g. starvation, diets below the basal metabolic rate, etc.).

\section{STATISTICAL ANALYSIS}

Obtained results were analysed statistically using STATISTICA 12 (Statsoft, Tulsa, Oklahoma, USA). Independent samples $\mathrm{T}$ test was used with respect to a variable. The level of statistical significance was $p \leq 0.05$.

\section{RESULTS}

\section{CHARACTERISTICS OF TEST GROUP}

The majority of examined patients lived in a city with $>100$ thousands of citizens (women: 60\% SG vs 70\% RYGB; men: $35.3 \%$ SG vs $69.2 \%$ RYGB), obtained secondary education (women: $60 \%$ SG vs $50 \%$ RYGB; men: $46.2 \%$ RYGB vs $53 \%$ SG). $80 \%$ of women and $84.6 \%$ of men qualified for RYGB, and 70\% of women and $76.5 \%$ of men subjected to SG led a sedentary lifestyle and did not undertake any physical activity (Table 3 ).

\section{PATIENTS QUALIFIED FOR ROUX-EN-Y GASTRIC BYPASS}

The average age of women was $44.75 \pm 12.21$, body mass index (BMI) $46.5 \pm 6.15 \mathrm{~kg} / \mathrm{m}^{2}$. The average age of examined men was $47.69 \pm 10.02$, BMI $43.11 \pm 6.57 \mathrm{~kg} / \mathrm{m}^{2}$.

\section{PATIENTS QUALIFIED FOR SLEEVE GASTRECTOMY}

The average age of examined women was $50.3 \pm 10.78$, BMI $48.45 \pm 6.69 \mathrm{~kg} / \mathrm{m}^{2}$. The average age of examined men was $47.19 \pm 9.93$, BMI $46.9 \mathrm{~kg} / \mathrm{m}^{2}$.

\section{DIETARY HABITS IN FEMALE PARTICIPANTS}

Most female participants (60\%) who qualified for both types of surgeries ate from 2 to 3 meals a day at irregular intervals (30\% RYGB vs $60 \%$ SG) and snacked in between meals (60\%). Women who reported snacking between meals and were qualified for SG confessed that they snacked under stress (71.43\%), and those who were qualified for RYGB - both in stressful situations (43.75\%) and when they were bored (43.75\%). Around $1 / 3$ of female patients who qualified for both procedures did not eat breakfasts. Additionally, some women reported that they ate meals during the night (15\% RYGB vs 30\% SG).

\section{DIETARY HABITS IN MALE PARTICIPANTS}

Most men qualified for RYGB claimed they ate 4-5 meals a day (53.85\%), and those qualified for SG from 2 to 3 meals a day (64.71\%). The majority of men qualified for RYGB reported that the intervals between their meals were irregular $(23.08 \%)$ or the intervals were 2-3 (23.08\%) and 8-9 (23.08\%) hours. The intervals between meals in case of men qualified for SG were from 3 to 4 hours $(29.41 \%)$. A significant percentage of men (38.46\%) qualified for RYGB reported that they snacked 
between meals, and a high percentage of those qualified for SG $(47.06 \%)$ claimed they did not snack. Majority of male patients (89\%) qualified for SG reported that they snacked in from of TV/computer. Most men qualified for RYGB reported that they snacked when they were bored (50\%) or in from of TV/computer (50\%). Men qualified for RYGB declared that they eat their breakfast within 30-60 minutes from getting up (46.15\%), and in the group of those qualified for SG $-29.41 \%$ eat breakfast within 30-60 minutes and $29.41 \%>1$ hour after getting up. Most of men qualified for both procedures reported that they did not eat meals at night $(69.23 \%$ RYGB vs $94.12 \%$ SG).

\section{COMPARE FEMALE AND MALE DIETARY HABITS}

The majority of women (60\%) and men $(56.7 \%)$ ate 2-3 main meals a day. Women (40\%) significantly more often than men $(20 \%)$ ate meals at irregular intervals ( $p=0.04)$. Twenty three percent of men declared that they eat their meals every 3-4 hours. Women significantly more often than men (60\% vs. $26.7 \%)$ snacked between meals $(p=0.01)$. Stress was a more frequent reason for women to snack ( $52 \%$ vs $15.8 \% ; p=0.04$ ), while men ate more often while watching TV (68.4 vs $26 \% ; p=0.04)$. The overwhelming number of women $(40 \%)$ ate breakfast $>1$ hour after waking up, and men (36.7\%) averaged 30-60 minutes after waking up. Most of the examined patients ( $85 \%$ of women vs. $83 \%$ of men) declared that they did not eat at night.

Details on dietary habits of patients qualified for RYGB and SG were presented in Table 4.

\section{DISCUSSION}

Majority of examined professionally active patients performed intellectual or mixed type of work, described their lifestyle as sedentary and reported that they did not undertake any physical activity. Similar results were observed by Vanhecke et al. [17], who showed that the majority of patients with morbid obesity led extremely sedentary lifestyles, and that there is a significant correlation between obesity, low physical activity and cardiovascular diseases. Additionally, improper dietary habits meant that patients consumed too few antioxidants from vegetables and fruits. The patients who were qualified for surgical obesity treatment should adhere to balanced and low-energy pre-operative diet, which aims at reducing body weight, delivering essential nutrients and supplement nutritional deficiencies, which increase the risk of the development of pre- and post-operative malnutrition. The results of the study show that the diets of patients are incompatible with current nutritional recommendations, and that their diets are deficient in polyunsaturated fatty acids, folic acid, potassium, vitamin D, calcium, iron and magnesium $[18,19]$. Patients with extreme obesity often suffer from deficiencies in folic acid, iron and vitamin $\mathrm{D}_{3}$ (among people qualified for RYGB) and folic acid, iron, vitamin $\mathrm{B}_{6}$ and $\mathrm{B}_{12}$ (among patients qualified for SG), which can escalate after the procedure [12]. Despite such alarming reports, there are very few studies focused on dietary habits of patients prepared for bariatric surgery. In the present study, most women qualified for bariatric surgery ate from 2 to 3 meals a day at irregular intervals. Most of men qualified for SG ate 2-3 meals a day every 3-4 hours, whereas those qualified for RYGB ate 4-5 meals a day at irregular intervals, or every 2-3 or 8-9 hours. In the study of Boniecka et al. [20] most patients (50\%) qualified for bariatric surgery ate 3 meals a day, whereas $30 \%$ patients ate 2 meals a day. In the study of Jastrzębska-Mierzyńska et al. [21], 71.8\% patients qualified for bariatric surgery ate their meals irregularly, and the intervals between the meals exceeded 4 hours. It was shown that the consumption of a daily food ration in 4-5 meals is favourable for maintaining proper body weight and is less related to the risk of excessive body mass gain than the consumption of fewer meals during the day. It was also shown that eating breakfasts is inversely proportional to the risk of obesity development [11] and that regularly eating breakfasts improves insulin resistance and glucose tolerance during subsequent meals and contributes to reduction of triglycerides and LDL levels in blood [22]. In the present study, $35 \%$ of women and $31 \%$ of men qualified for RYGB and $30 \%$ of women and $18 \%$ of men qualified for SG did not eat breakfasts, which contributed to obesity.

Moreover, in the present study as much as $15 \%$ of women and $31 \%$ of men qualified for RYGB, and $30 \%$ of women and $6 \%$ of men qualified for SG, reported eating during the night. In the study of Colles et al. [23] the night eating syndrome was observed in $17.1 \%$ patients qualified for bariatric surgery, and its occurrence was more probable among men than women. Night eating syndrome is one of eating disorders which may accompany obesity. It occurs in $1-2 \%$ of total population, in $8-15 \%$ of obese people and even in $24 \%$ of people qualified to bariatric surgery. It relates to lower psychological quality of life, depression, anxiety and other eating disorders [24, 25].

Psychological aspects play an important role among the factors predisposing to the development of obesity. This relates to, among others, disrupted self-control mechanisms, negative emotions and their expression or inability to control stress [26]. Reaching for food under stress is a factor which relieves tension and anxiety and causes relief. Thus, it may lead to overeating resulting in obesity. Consequently, a patient falls into a vicious circle - negative health effects of obesity and deterioration of psychical comfort occur, which decrease the quality of life and lead to further overeating to lower the level of stress [24, 27]. In this study, $60 \%$ of women qualified to both types of procedures and $39 \%$ of men qualified for RYGB reported they were eating between the meals. Most of men qualified for SG declared they did not snack and 35\% confirmed they sometimes snacked between the meals. Women, who were qualified for SG reported that they most often snacked due to stress, and those 
TABLE 4. Dietary habits of patients

\begin{tabular}{|c|c|c|c|c|c|c|}
\hline \multirow[t]{2}{*}{ Variable } & \multicolumn{3}{|c|}{ Women } & \multicolumn{3}{|c|}{ Men } \\
\hline & RYGB (\%) & SG (\%) & $\begin{array}{c}\text { Statistical } \\
\text { analysis }\end{array}$ & RYGB (\%) & SG (\%) & $\begin{array}{c}\text { Statistical } \\
\text { analysis }\end{array}$ \\
\hline \multicolumn{7}{|l|}{ Number of meals per day } \\
\hline 1 & 5 & 0 & NS & 0 & 0 & NS \\
\hline $2-3$ & 60 & 60 & NS & 46.15 & 64.71 & NS \\
\hline $4-5$ & 15 & 40 & NS & 53.85 & 35.29 & NS \\
\hline$>6$ & 20 & 0 & NS & 0 & 0 & NS \\
\hline \multicolumn{7}{|c|}{ Intervals between the meals (hours) } \\
\hline $1-2$ & 5 & 0 & NS & 0 & 11.76 & NS \\
\hline $2-3$ & 15 & 0 & NS & 23.08 & 0 & NS \\
\hline $3-4$ & 0 & 0 & NS & 15.38 & 29.41 & NS \\
\hline $4-5$ & 10 & 10 & NS & 15.38 & 5.88 & NS \\
\hline $6-7$ & 15 & 20 & NS & 0 & 17.65 & NS \\
\hline $8-9$ & 20 & 10 & NS & 23.08 & 17.65 & NS \\
\hline 24 & 5 & 0 & NS & 0 & 0 & NS \\
\hline Irregular & 30 & 60 & NS & 23.08 & 17.65 & NS \\
\hline \multicolumn{7}{|c|}{ Snacking between the meals } \\
\hline Yes & 60 & 60 & NS & 38.46 & 17.65 & NS \\
\hline No & 20 & 30 & NS & 23.08 & 47.06 & NS \\
\hline Sometimes & 20 & 10 & NS & 38.46 & 35.29 & NS \\
\hline \multicolumn{7}{|l|}{ Reasons for snacking } \\
\hline Stress/anxiety & 43.75 & 71.43 & NS & 20 & 11.11 & NS \\
\hline Boredom & 43.75 & 28.57 & NS & 50 & 22.22 & NS \\
\hline $\begin{array}{l}\text { Habit in front of TV/ } \\
\text { computer }\end{array}$ & 31.25 & 14.29 & NS & 50 & 88.89 & NS \\
\hline \multicolumn{7}{|c|}{ Time from getting up to breakfast } \\
\hline Up to 30 minutes & 10 & 10 & NS & 0 & 23.53 & NS \\
\hline $30-60$ minutes & 15 & 20 & NS & 46.15 & 29.41 & NS \\
\hline$>1$ hour & 40 & 40 & NS & 23.08 & 29.41 & NS \\
\hline No breakfasts & 35 & 30 & NS & 30.77 & 17.65 & NS \\
\hline \multicolumn{7}{|l|}{ Eating at night } \\
\hline Yes & 15 & 30 & NS & 30.77 & 5.88 & NS \\
\hline No & 85 & 70 & NS & 69.23 & 94.12 & NS \\
\hline
\end{tabular}

RYGB - Roux-en-Y gastric bypass, SG - sleeve gastrectomy, NS - statistically insignificant, meal - food that is eaten for the main meals of the day (e.g. breakfast, lunch, dinner, super), snacking - eating small amounts of food between meals (e.g. chips, sweets)

qualified for RYGB - both due to stress and boredom. In the study by Ferguson et al. [28], majority of patients $(63 \%)$ qualified for bariatric surgery regarded stress as the cause of body mass gain. Eating under stress is connected to lower than expected body weight reduction after surgical treatment of obesity [29]. It was shown that psycho-emotional factors play a crucial role in the development of obesity. Stress contributes to higher secretion of cortisol by affecting the axis hypothalamus - pituitary gland - adrenal cortex [30]. Cortisol inhibits peripheral use of glucose, stimulates the secretion of leptin and activity of lipoprotein lipase. Higher density of glucocorticoid receptors localized in visceral tissue indicates locally more pronounced glucocorticoid effects. This leads to redistribution of fatty tissue which starts to accumulate in the region of abdominal cavity, resulting in the development of insulin resistance, type 2 diabetes and metabolic syndrome [31]. 
It is important to educate the patients that long-lasting body mass reduction after bariatric surgery is possible only when they change their dietary habits permanently and become constantly physically active [32]. It has been proved that the lack of physical activity and low quality of the diet are related to renewed body mass gain after surgical treatment of obesity [33].

\section{CONCLUSIONS}

1. The lack of physical activity and sedentary lifestyle may be one of the main reasons of obesity.

2. Such factors as: not eating breakfasts, too few meals during the day, and long, irregular intervals between meals, may be regarded as nutritional causes of obesity.

3. Women more often attempt to reduce stress and monotony by eating, thus the support of a psychologist and finding an interesting hobby would help in their body mass reduction.

4. It is necessary to introduce a widespread nutritional education among the patients fighting with obesity both before and after surgical treatment.

\section{ACKNOWLEDGMENTS}

The project was approved by the Bioethical Committee of Pomeranian Medical University (resolution No. KB-0012/34/04/2014). Informed consent was obtained from all individual participants included in the study.

\section{DISCLOSURE}

The authors report no conflict of interest.

\section{References}

1. Jastrzębska M, Ostrowska L. Zalecenia dietetyczne po zabiegach bariatrycznych [Dietary recommendations for bariatric surgery patients]. Forum Zaburzeń Metabolicznych 2010; 1 (4): 201-209.

2. Gallus S, Lugo A, Murisic B, et al. Overweight and obesity in 16 European countries. Eur J Nutr 2015; 54 (5): 679-689.

3. World Health Organization. Obesity and overweight. Available from: http://www.who.int/mediacentre/factsheets/fs311/en/ (accessed: 26 August 2017)

4. Borovicka J, Krieger-Grübel C, van der Weg B, et al. Effect of morbid obesity, gastric banding and gastric bypass on esophageal symptoms, mucosa and function. Surg Endosc 2017; 31 (2): 552-560.

5. Nowakowska-Zajdel E, Muc-Wierzgoń M, Kokot T, et al. Serum insulin levels in patients with colorectal cancer. Pol Arch Med Wewn 2008; 118 (5): 273-279.

6. Pischom T, Boeing H, Hoffmann K, et al. General and abnormal adiposity and risk of death in Europe. N Engl J Med 2008; 359 (20): 2105-2120.

7. Aquirre PF, Coca A, Aquirre MF, Celis G. Waist-to-height ratio and sedentary lifestyle as predictors of metabolic syndrome in children in Ecuador. Hipertens Riesgo Vasc 2018; 35 (3): 101-109.
8. Marlicz W, Ostrowska L, Łoniewski I. Flora bakteryjna jelit i jej potencjalny związek z otyłością [Intestinal bacterial flora and its potential relations with obesity]. Endokrynol Otył Zab Przem Mat 2013; 9 (1): 20-28.

9. Drewnowski A. Nutrient density: addressing the challenge of obesity. B J Nutr 2018; 120 (s1): S8-S14.

10. Croezen S, Visscher TLS, Ter Bogt NCW, et al. Skipping breakfast, alcohol consumption and physical inactivity as risk factors for overweight and obesity in adolescents: results of the E-MOVO project. Eur J Clin Nutr 2009; 63 (3): 405-412.

11. Damms-Machado A, Friedrich A, Kramer KM, et al. Pre- and postoperative nutritional deficiencies in obese patients undergoing laparoscopic sleeve gastrectomy. Obes Surg 2012; 22 (6): 881-889.

12. Ernst B, Thurnheer M, Schmid SM, Schultes B. Evidence for the necessity to systematically assess micronutrient status prior to bariatric surgery. Obes Surg 2009; 19 (1): 66-73.

13. Bavaresco M, Paganini S, Lima TP, et al. Nutritional course of patients submitted to bariatric surgery. Obes Surg 2010; 20 (6): 716-721.

14. Kostecka M, Bojanowska M. Problems in bariatric patient care - challenges for dieticians. Wideochir Inne Tech Maloinwazyjne 2017; 12 (3): 207-215.

15. Gastrointestinal surgery for severe obesity: National Institutes of Health Consensus Development Conference Statement. Am J Clin Nutr 1992; 55 (2 Suppl): 615S-619S.

16. Pucci A, Batterham RL. Mechanisms underlying the weight loss effects of RYGB and SG: similar, yet different. J Endocrinol Invest 2019; 42 (2): 117-128.

17. Vanhecke TE, Franklin BA, Miller WM, et al. Cardiorespiratory fitness and sedentary lifestyle in the morbidly obese. Clin Cardiol 2009; 32 (3): 121-124.

18. Jastrzębska-Mierzyńska M, Ostrowska L, Hady R, Dadan J. Assessment of dietary habits, nutritional status and blood biochemical parameters in patients prepared for bariatric surgery: a preliminary study. Wideochir Inne Tech Maloinwazyjne 2012; 7 (3): 156-165

19. Jastrzębska-Mierzyńska M, Ostrowska L, Wasiluk D, Konarzewska-Duchnowska E. Dietetic recommendations after bariatric procedures in the light of the new guidelines regarding metabolic and bariatric surgery. Rocz Panstw Zakl Hig 2015; 66 (1): 13-19.

20. Boniecka I, Szczygieł B, Paśnik K. Wybrane cechy trybu życia pacjentów z otyłością olbrzymią zakwalifikowanych do operacji bariatrycznych [Selected lifestyle characteristic of patients with extreme obesity qualified for bariatric surgery]. Roczn Panstw Zakl Hig 2009; 60 (3): 279-284.

21. Jastrzębska-Mierzyńska M, Ostrowska L, Hady R, et al. Dietary habits of obese patients qualified for bariatric procedures. Rocz Panstw Zakl Hig 2014; 65 (1): 41-47.

22. Mekary RA, Giovannucci E, Willett WC, et al. Eating patterns and type 2 diabetes risk in men: breakfast omission, eating frequency, and snacking. Am J Clin Nutr 2012; 95 (5): 1182-1189.

23. Colles SL, Dixon JB, O'Brien PE. Grazing and loss of control related to eating: two high-risk factors following bariatric surgery. Obesity(Silver Spring) 2008; 16 (3): 615-622. 
24. Bąk-Sosnowska M. Zaburzenia odżywiania towarzyszące otyłości [Dietary disorders accompanying obesity]. Forum Zaburzeń Metabolicznych 2010; 1 (2): 92-99.

25. Olbrich K, Mühlhans B, Allison KC, et al. Night eating, binge eating and related features in patients with obstructive sleep apnea syndrome. Eur Eat Disord Rev 2009; 17 (2): 120-127.

26. Juruć A, Wierusz-Wysocka B, Bogdański P. Psychologiczne aspekty jedzenia i nadmiernej masy ciała [Psychological aspects of food and overweight]. Farm Współ 2011; 4: 119-126.

27. Bąk-Sosnowska M. Miejsce psychologa w leczeniu otylosci [A space for a psychologist in obesity treatment]. Forum Med Rodz 2009; 3 (4): 297-303.

28. Ferguson S, Al-Rehany L, Tang C, et al. Self-reported causes of weight gain among prebariatric surgery patients. Can J Diet Pract Res 2013; 74 (4): 189-192.

29. Toussi R, Fujioka K, Coleman KJ. Pre- and postsurgery behavioural compliance, patient health, and postbariatric surgical weight loss. Obesity (Silver Spring) 2009; 17 (5): 996-1002.

30. Białkowska M. Etiopatogeneza otyłości [Etiopathogenesis of obesity]. Post Nauk Med 2011; XXIV (9): 765-769.

31. Siemińska L. Tkanka tłuszczowa. Patofizjologia, rozmieszczenie, różnice płciowe oraz znaczenie w procesach zapalnych i nowotworowych [Adipose tissue. Pathophysiology, distribution, sex differences and the role in inflammation and cancerogenesis]. Endokrynol Pol 2007; 58 (4): 330-342.

32. Hwang KO, Childs JH, Goodrick GK, et al. Explanation for unsuccessful weight loss among bariatric surgery candidates. Obes Surg 2009; 19 (10): 1377-1383.

33. Freire RH, Borges MC, Alvarez-Leite JI, et al. Food quality, physical activity and nutritional follow-up as determinant of weight regain after Roux-en-Y gastric bypass. Nutrition 2012; 28 (1): $53-58$

\section{AUTHORS' CONTRIBUTIONS}

NK, MS, MH and KK prepared research concept and design. $\mathrm{NK}, \mathrm{MH}$ and BK collected data. NK and MS analysed data, wrote the article and critically revised it. NK, MS, BK, and KK finally approved the publication. 